\title{
Iron deficiency for prognosis in acute coronary syndrome - a systematic review and meta-analysis
}

Johannes Reinhold ${ }^{1 *}$, MD, PhD, Med State Exam, MRCP, MSc, BSc, FHEA Charikleia Papadopoulou ${ }^{2 *}$, MBBS, MRCP, PhD, BSc

Ranu Baral ${ }^{3}$, MRes, MBBS

Vassilios S Vassiliou', MA, MBBS, PhD, FRCP, FESC, FACC

1) University of East Anglia (UEA), Norwich Research Park, Norwich, NR4 7TJ, United Kingdom; Norfolk and Norwich University Hospital, Colney Lane Norwich, NR4 7UY.

This author takes responsibility for all aspects of the reliability and freedom from bias of the data presented and their discussed interpretation.

2) University of Cambridge, The Old Schools, Trinity Ln, Cambridge CB2 1TN, United Kingdom; Royal Papworth Hospital, Papworth Road, Cambridge

Biomedical Campus, Cambridge, CB2 OAY.

This author takes responsibility for all aspects of the reliability and freedom from bias of the data presented and their discussed interpretation.

3) University of East Anglia (UEA), Norwich Research Park, Norwich, NR4 7TJ, United Kingdom; Norfolk and Norwich University Hospital, Colney Lane Norwich, NR4 7UY.

This author takes responsibility for the production of forest plots, advised on meta-analysis methodology and edited the manuscript.

*These authors contributed equally to this work.

\section{Corresponding author:}

Johannes Reinhold, University of East Anglia (UEA), Norwich Research Park, Bob Champion Building, Norwich, NR4 7TJ

J.Reinhold@uea.ac.uk

Fax: +44 (0)1603 597019

Tel: +44 (0)1603 597001

\section{Acknowledgement of grant support}

No specific grant support was received for this project; JR and CP received salary through a National Institute of Health Clinical Lecturer post.

\section{Conflict of interest}

The authors report no relationships that could be construed as a conflict of interest

\section{Keywords}

Acute coronary syndrome, myocardial infarction, iron deficiency, prognosis, meta-analysis 


\section{Abstract}

Background: Iron deficiency (ID) is an important predictor of adverse outcomes in patients with heart failure, however it is unclear whether ID also affects prognosis in patients with acute coronary syndrome (ACS). The aim of this systematic review and meta-analysis was to assess the prognostic value of iron deficiency in patients with ACS.

Methods: We searched PubMed, Web of Science, and the Cochrane library and included cohort studies of patients with ACS that were stratified by ID status. There were no restrictions on definition of ACS or ID. Studies were systematically appraised and data extracted by two independent reviewers. Meta-analysis was performed where two or more studies reported on the same pre-determined outcome measure.

Results: Seven studies with 2821 participants were identified, reporting a high prevalence of ID in the ACS population. Three studies reported worse longterm outcomes in the ID population, whereas short-term outcomes were heterogeneous across studies.

Conclusions: Patients with ID presenting with ACS may have a worse longterm prognosis but more studies are required for confirmation. A role for ID in prognosis of patients with ACS and as a potentially treatable condition may have implication for the current management of this patient population. 


\section{Introduction}

Iron is an important micronutrient essential for basic cellular processes and with its homeostasis tightly regulated ${ }^{1,2}$. It is essential for oxygen transport (hemoglobin) and storage (myoglobin), mitochondrial function, skeletal and cardiac muscle metabolism, synthesis and degradation of proteins, lipids and ribonucleic acids as well as immune and neural function ${ }^{3-5}$. The most frequently used definition of iron deficiency (ID) in patients with cardiovascular disease is ferritin $<100 \mu \mathrm{g} / \mathrm{L}$ (absolute ID) or ferritin 100-299 $\mu \mathrm{g} / \mathrm{L}$ and transferrin saturation (TSAT) $<20 \%$ (functional ID) ${ }^{6-8}$, however in this systematic review and meta-analysis no restrictions were placed on the definition of ID.

ID, with or without anemia, has been identified as an important predictor of adverse outcomes in patients with heart failure and intravenous replacement has been shown to improve prognosis $6,7,9,10$. Although ID is highly prevalent in patients with coronary artery disease ${ }^{11,12}$, a role of ID on outcomes in patients with acute coronary syndrome (ACS) is not well established. In this systematic review and meta-analysis we assessed the effects of ID on outcomes in patients presenting with ACS. All studies assessing patients with ACS were eligible if reporting on one of the pre-determined outcomes including survival, major adverse cardiac endpoint (MACE), left ventricular ejection fraction (LVEF), troponin concentration, Killip class or creatinine concentration.

\section{Methods}


This systematic review and meta-analysis was conducted according to the Preferred Reporting Items for Systematic Reviews and Meta-analyses (PRISMA) guidelines ${ }^{13}$.

\section{Types of studies, outcome measures and inclusion and exclusion}

\section{criteria}

We planned to include case control studies, cohort studies and randomized controlled trials comparing morbidity and mortality of patients with or without ID irrespective of anemia status following an ACS. We included studies reported as full-text and also those reported in abstract form only as this is an evolving area of research. We included all participants with a diagnosis of ACS including patients with unstable angina, ST-Elevation Myocardial Infarction (STEMI) and non ST-Elevation Myocardial Infarction (NSTEMI) ${ }^{14}$. Patients needed to be stratified by iron status, i.e. classified as 'iron deficient' or 'non-iron deficient' without restrictions on the exact definition of ID. Studies were included if they reported on at least one of the predetermined outcome measures. The primary outcome was overall long-term mortality and major adverse cardiovascular events (MACE), secondary outcomes were short-term survival, MACE, left ventricular ejection fraction (LVEF), troponin concentrations, length of hospital stay, Killip class, creatinine concentrations, functional capacity, quality of life and we also considered other outcomes reported in included studies.

We did not examine studies investigating the effects of free or catalytic iron on outcomes after acute coronary syndromes or examining the association of ID with incident myocardial infarction. 


\section{Search methods for identification of studies for review}

We searched PubMed, Web of Science Core Collection and the Cochrane Library, from inception until $4^{\text {th }}$ of June 2020 without language restrictions or filters. The search term used was: ("ferritin*" OR "Iron*" OR "transferrin*" OR "Ferrous*") AND (myocardial infarction OR acute coronary syndrome OR STEMI* OR NSTEMI*). Reference lists of studies included in the systematic review were screened for additional references.

\section{Data collection and analysis}

After removal of duplicates, two reviewers (JR and CP) independently screened titles and abstracts of all records. Articles were assessed for inclusion in the meta-analysis based on the presence of at least one of the outcome measures (either primary or secondary) in our participant groups by two independent reviewers (CP and JR). Any disagreements were resolved through discussion or by a third review author (VV). The selection process was documented to allow completion of a PRISMA flow diagram and a PRISMA checklist has been completed (supplemental material).

\section{Data extraction and management}

We used endnote $X 7$ for screening of studies for inclusion in systematic review and meta-analysis including identifying and removing of duplicates. Two authors (JR and CP) extracted the following data from the included studies using a standardized data collection sheet: 1) methods: type of study, duration or length of follow up, number of centers, dates of study; 2) 
participants: total number of participants with ACS, number identified with ID and without ID, mean/median age, age range, gender; 3) outcomes: primary and secondary outcomes as described; 4) other features deemed important by the reviewer, e.g. conflicts of interest by authors or sources of funding.

\section{Risk of bias assessment of included studies}

Risk of bias in all included studies was assessed using the QUIPS tool ${ }^{15}$, through ranking of six domains as low, moderate or high risk by two independent reviewers (JR and CP).

\section{Quantification of outcome measures}

For all other outcomes we collected data and reported odds ratios (ORs) with confidence intervals (Cls) for dichotomous data and mean differences (MDs) with $95 \%$ Cls when possible. For short-term in-hospital outcomes, mortality and cardiovascular mortality data was pooled.

\section{Data synthesis}

Meta-analysis was performed when at least two studies were identified that reported on the same outcome measure. All data was analyzed using random effects models in OpenMeta[Analyst] software version 10.12 (developed by the Centre for Evidence Synthesis, Brown University, School of Public Health, Rhode Island State, USA) and presented with 95\% Cls.

\section{Assessment of heterogeneity and reporting biases}


Heterogeneity was assessed both qualitatively through comparing characteristics of the included studies and through the $\mathrm{I}^{2}$ statistic in each analysis with statistical significance defined as $p<0.05$.

\section{Subgroup analysis and sensitivity analysis}

We planned to carry out the following pre-determined subgroup analyses: Anemic vs non-anemic patients and male vs female. If enough data was available, we planned to perform a sensitivity analysis including only studies with a low risk of bias score across all domains.

\section{Results}

\section{Search results}

Our search yielded 3053 results (see PRISMA flow chart, Figure 1). We removed 608 duplicates and screened titles and abstracts of 2445 records. Of these 67 items were identified for full-text review. A total of sixty records were excluded (Figure 1). Some 26 excluded studies did not address the question of the review, for example studies that reported on an association between ferritin and myocardial infarction without allowing stratification of patients as 'iron-deficient' or 'not iron-deficient'. Other important reasons for exclusion were duplicate reports of the same study (10 records) and focus on anemia rather than ID (9 records). Seven records were included in the narrative synthesis and meta-analysis where at least two studies reported on the same outcome. 
No study described the effect of ID on length of hospital stay and not enough studies were identified to perform the pre-defined subgroup and sensitivity analyses.

\section{Included studies, risk of bias assessment and prevalence of ID} Characteristics of the included studies are summarized in Table 1. A risk of bias assessment is summarized in Table 2. Studies identified were generally relatively small studies with high heterogeneity of participants included. Prevalence of ID ( $N=1226,43 \%)$ was high in patients with ACS $(\mathrm{N}=2821)$ across all included studies (Figure 2A).

\section{Primary endpoint}

\section{Long-term mortality and MACE}

Only two studies reported on long-term all-cause mortality in patients with and without ID ${ }^{16,17}$ but achieving very different lengths of follow up and thus metaanalysis was not performed. Gonzalez-D'Gregorio, et al. ${ }^{16}$ investigated the role of ID in 252 elderly patients with ACS (Prevalence of ID and anemia were $59.9 \%$ and $47.2 \%$, respectively). The authors found a trend towards increased risk of mortality for patients with ID (log-rank test $p=0.06)$ during a median follow-up of 4.7 years (IQR: 2-5.4) but no numerical values for this increased risk were provided. The data was supported by analysis of TSAT levels across the patient population, which were found to be inversely, and nonlinearly associated with the risk of long-term mortality $(p=0.002)$ after multivariate adjustment. Martins, et al. ${ }^{17}$ found a higher six-months mortality 
in patients with ACS and ID compared to non-ID (9.5\% vs. 3.1\%, p=0.004) and functional ID (TSAT $<20 \%$ and ferritin $>100 \mu \mathrm{g} / \mathrm{L}$ ) was a predictor of sixmonths mortality (HR 2.9, $\mathrm{p}=0.023)$ independently of anemia.

Only one study reported on long-term MACE defined as myocardial infarction and cardiovascular mortality ${ }^{11}$. This study is a retrospective subgroup analysis of patients with ACS from the AtheroGene cohort study. 836 patients (ID was present in $29.1 \%$ of patients in total, $42.8 \%$ in women and $42.5 \%$ in patients with anemia) were included with a mean follow up of four years. Patients with ID had a HR of $1.50(95 \% \mathrm{Cl} 1.02$ to $2.20, \mathrm{p}=0.04)$ for MACE compared to non-ID. This association remained robust when adjusted for age, sex, hypertension, smoking status, diabetes, hyperlipidemia and BMI (HR $1.52,95 \% \mathrm{Cl} 1.03$ to $2.26, \mathrm{p}=0.037$ ) and when additionally adjusted for hemoglobin, NT-proBNP and troponin I (HR 1.73, 95\% Cl 1.07 to 2.81 , $\mathrm{p}=0.026$ ).

\section{Secondary end points}

\section{Short-term mortality}

Only one study reported on 30-day mortality differences between ID and non$I^{12}$. This study prospectively enrolled 420 patients with STEMI, but mortality rates in the short term were low. 30-day mortality was $3 \%(n=7)$ in the ID group and $5 \%(n=10)$ in the non-ID group $(p=0.19)$.

Two studies reported on in-hospital mortality ${ }^{12,18}$ with contradictory overall findings (Figure 2B). Whilst Cosentino, et al. ${ }^{12}$ report numerically reduced cardiovascular mortality for patients with ID compared to non-ID (2\% vs $4 \%$, 
$p=0.14$ ), Fujinaga, et al. ${ }^{18}$ found increased in-hospital mortality for patients with ID $(6.5 \%$ versus $1.6 \%, p=0.03)$.

\section{Short-term adverse events and MACE}

Cosentino, et al. ${ }^{12}$ used a composite end point of in-hospital mortality and Killip class $\geq 3$ with an adverse outcome observed in 23 patients (10\%) in the ID group and 33 patients (18\%) in the non-ID group $(p=0.01)$. The unadjusted OR for this endpoint was $0.48(95 \% \mathrm{Cl} 0.28$ to $0.87, \mathrm{p}=0.01)$ and when adjusted for diabetes mellitus, admission high-sensitivity troponin I and hemoglobin the $\mathrm{OR}$ was $0.50(95 \% \mathrm{Cl} 0.27$ to $0.93, \mathrm{p}=0.02)$. In contrast, Martins, et al. ${ }^{17}$ reported higher in-hospital MACE for patients with ID compared to non-ID ( $41 \%$ vs. $18 \%$; $p<0.001)$.

\section{LVEF}

No studies reported on long-term effects of ID on LVEF after ACS. One study reported 30-day LVEF ${ }^{19}$. Patients with ID defined as ferritin $<100 \mu \mathrm{g} / \mathrm{L}$ had an LVEF of $51.6 \%$ compared to $55.5 \%$ in patients with normal ferritin $(p=0.04)$. Three studies reported on in-hospital LVEF in patients with ID compared to non-ID ${ }^{12,18,20}$, two of which suggesting a numerically reduced LVEF in patients with ID ${ }^{18,20}$ and one reporting no difference ${ }^{12}$ (Figure 2C).

\section{Troponin concentrations}

Three studies reported on peak troponin concentrations ${ }^{12,19,20}$ but metaanalysis was not performed due to the use of different troponin assays and reporting formats. Cosentino, et al. ${ }^{12}$ reported similar peak high-sensitivity 
troponin I concentrations in ID compared to non-ID patients $(31,568[11,760-$ $80,835] \mathrm{ng} / \mathrm{L}$ and $30,960[15,177-69,720] \mathrm{ng} / \mathrm{L}$, respectively, $\mathrm{P}=0.54)$.

Similarly, Meroño, et al. ${ }^{20}$ found comparable peak high-sensitivity troponin T concentrations in both groups (1259 [271-4691] ng/L for ID vs. 1038 [2883302] $n g / L$ for non-ID, $p=0.662$ ). Only Paeres, et al. ${ }^{19}$ discovered borderline lower peak troponin I concentrations in patients with ID $(14 \mathrm{ng} / \mathrm{ml})$ compared to patients with normal ferritin profile $(30 \mathrm{ng} / \mathrm{ml}, \mathrm{p}=0.05)$.

One study reported higher admission troponin I concentrations in the ID group $(231 \pm 66 \mathrm{ng} / \mathrm{L})$ compared to the non-ID group $(145 \pm 35 \mathrm{ng} / \mathrm{L}, \mathrm{p}<0.001)^{12}$.

\section{Killip class}

Four studies reported on Killip class in patients with and without ID ${ }^{12,18-20}$. The authors of these studies reported conflicting effects of ID on Killip class, with two studies reporting favorable outcome in patients with $\mathrm{ID}^{12,19}$ and two studies suggesting worse outcome in patients with ID ${ }^{18,20}$ (Figure 2D, metaanalysis of three studies using same comparison).

\section{Creatinine concentrations}

Two studies reported on creatinine concentrations ${ }^{12,20}$ on admission with no significant differences between ID and non-ID (Figure 2E).

\section{Functional capacity}

Only Meroño, et al. ${ }^{20}$ reported on exercise capacity in a subgroup of their study population at 30-day follow up. Significantly more patients in the ID group were unable to undergo exercise testing compared to non-ID ( $41 \%$ had 
ID in group completing exercise testing compared to $66 \%$ who had ID in the group not-completing exercise testing, $\mathrm{p}<0.001)$. In the treadmill group, patients with ID had lower total exercise time and lower metabolic consumption compared to patients without ID (7.9 \pm 2.9 vs. $9.3 \pm 2.6 \mathrm{METS}$, $p=0.003$ and $366 \pm 162$ vs. $462 \pm 155$ seconds; $p<0.001)$. In the 13 patients who could not undergo treadmill testing but were able to complete a 6-minute walk test, shorter distances were observed in the ID group compared to the non-ID group (277 vs. 423 meters, $p=0.009$ ).

\section{Quality of life}

Meroño, et al. ${ }^{20}$ also reported on quality of life measures at day 30 post ACS 20. The authors found lower scores in the ID group across a visual analogue scale [points (SD), 66 (16) for ID vs. 72 (17) for non-ID, $p=0.008)$, the EQ-5D index [value (SD), $0.76(0.25)$ for ID vs. $0.84(0.16)$ for non-ID, $p=0.005$ ], and the Heart-QoL global coefficient [value (SD), 1.9 (0.6) for ID vs. $2.2(0.6)$ for non-ID, $p=0.004]$.

\section{Other outcome measures}

Cosentino, et al. ${ }^{12}$ reported no statistically significant differences for patients with or without ID across the following in-hospital outcomes: mechanical ventilation, atrial fibrillation, VT/VF and atrio-ventricular block. In the cardiac magnetic resonance $(\mathrm{CMR})$ arm of their study, the authors found a larger myocardial salvage index in the ID group compared to the non-ID group $(0.56 \pm 0.30$ for ID vs. $0.43 \pm 0.27$ for non-ID, $p=0.002)$ and less microvascular obstruction (MVO, grams, $3.6 \pm 2.2$ for ID vs. $6.9 \pm 3.9$ for non-ID, $p<0.001$ ). The 
same authors also reported significantly higher mitochondrial DNA copy numbers in the ID group compared to non-ID [mtDNA, copies/ $\mu$ I (IQR), 1368 (908-4260) for ID vs. 917 (404-1748) for non-ID, $p=0.003]^{12}$. Fujinaga, et al. ${ }^{18}$ found significantly less ST segment resolution in the ID group compared to the non-ID group (58\% vs. $72 \%, p=0.005)$.

\section{Discussion}

To the best of our knowledge, this is the first systematic review and metaanalysis examining the role of ID for prognosis after ACS irrespective of anemia status. Any association of ID with outcomes after ACS would be of considerable importance due to high prevalence of ID in this population. Because ID is readily treatable, an association may have important implications for further research on iron substitution in this patient group. Despite the importance of ID in cardiovascular diseases ${ }^{6-9}$, we found only a limited amount of studies examining an association of ID in patients with ACS. The three studies that assessed long-term prognosis identified through this systematic review found a worse prognosis for patients with ID compared to non-ID when measured as all-cause mortality ${ }^{16,17}$ or a combined end-point of non-fatal MI and cardiovascular mortality ${ }^{11}$. Furthermore, exercise capacity and quality of life were significantly reduced in patients with ID at 30-day follow up ${ }^{20}$. In contrast, the short-term in-hospital outcomes that were reported here were conflicting ${ }^{12,17-20}$. Iron plays a crucial role in mitochondrial biology ${ }^{4}$ and mitochondrial dysfunction is a major source of reactive oxygen species (ROS) during ischemia/reperfusion injury generated through reverse electron transfer by the 
iron cluster rich complex I ${ }^{21,22}$. Cosentino, et al. ${ }^{12}$ hypothesized that patients with ID have decreased reperfusion injury based on data from the CMR arm of their study showing a greater myocardial salvage index and less microvascular obstruction in patients with ID. Mechanistically, iron, through its effect on ROS could influence apoptosis and necrosis of cardiomyocytes thereby exacerbating damage caused by the ischemic period itself. A considerable amount of research has also focused on adverse effects of free iron (also referred to as catalytic iron or labile iron) through its association with coronary artery disease and production of ROS during myocardial infarction and reperfusion ${ }^{23-26}$. However, a randomized controlled trial failed to demonstrate reduced infarct size with deferoxamine, an iron chelating agent in patients with STEMI ${ }^{27}$. Thus further mechanistical studies examining the effects of iron during myocardial infarction and reperfusion are warranted. A prognostic role for long-term adverse effects of ID in the ACS population is plausible. Firstly, ID has been established as a marker for adverse outcome in patients with heart failure ${ }^{6-8}$, a well-established complication of myocardial infarction. Secondly, ID is associated with adverse all cause mortality in seemingly healthy individuals. This is exemplified by the Gutenberg Health Study ( $\mathrm{n}=5000$ ), which found, after correction for hemoglobin and major cardiovascular risk factors, hazard ratios for all cause mortality of $1.3(1.0-$ 1.6, $\mathrm{p}=0.023)$ for functional ID and $1.9(1.3-2.8, \mathrm{p}=0.002)$ for absolute ID ${ }^{28}$. Thirdly, as ID is associated with chronic disease states including chronic inflammatory states and cancers ${ }^{1}$, such confounding diseases could further contribute to mortality in addition to cardiovascular disease. 
Further large-scale studies are required to confirm an association between ID and adverse long-term outcomes after ACS. However, because all studies with long-term follow up included in this systematic review reported adverse effects of ID on prognosis it is important to determine whether correction of ID with iron supplementation improves long-term outcome in this patient population. Given the safety profile of intravenous iron supplementation and the prognostic benefit in patients with heart failure ${ }^{6-8}$, and the equipoise observed, a randomized controlled trial investigating this therapeutic approach in patients with ACS is urgently needed.

\section{Limitations of this systematic review}

Various definitions of ID have been used in the studies included in this review. When relying on ferritin measurement, their use may have limitations in patients with ACS because ferritin, an acute phase protein, increases after myocardial infarction ${ }^{29,30}$. However, the definition of iron deficiency that is most frequently used in cardiac patients (ferritin $<100 \mu \mathrm{g} / \mathrm{L}$ or $100-299 \mu \mathrm{g} / \mathrm{L}$ and TSAT<20\%) also incorporates low transferrin saturations thereby mitigating the effect of the acute phase reaction ${ }^{6-8}$. Nevertheless, it has been estimated that this definition only has a sensitivity of $82 \%$ and specificity of $72 \%$ for the detection of ID when compared to the gold standard of bone marrow iron status at least in a heart failure population ${ }^{31}$. Thus further standardization and validation of laboratory measurements of iron status are needed to accurately diagnose ID in the ACS cohort. 
The studies included in this meta-analysis had considerable risk of bias and used different endpoints thus making comparisons challenging. Individual data meta-analysis would produce more accurate results.

\section{Conclusions}

We show that only a few studies assessed the effect of ID on prognosis after myocardial infarction. This is an important area of research with implications on direct patient care as ID is highly prevalent in this cohort. In long-term follow up detrimental effects of ID have been observed in all three studies identified whereas evidence on the short-term predictive value of ID in ACS is inconclusive and further studies are required. As iron supplementation is considered safe and might be beneficial, a randomized controlled trial should investigate this therapeutic approach in patients with ACS and ID.

\section{Authors' contributions}

JR conceived, planned and designed the study, executed systematic review and meta-analysis and drafted manuscript. CP conceived study, executed systematic review and significantly amended manuscript. RB executed metaanalysis and amended manuscript. VV planned and designed the study, supervised systematic review and meta-analysis and significantly amended the manuscript. *JR and CP contributed equally to this work.

\section{Sources of Funding}


The authors have not received a specific grant for this research. JR and CP received funding for their clinical lecturer salaries from the National Institute of Health Research (NIHR).

\section{Disclosures}

None

\section{References:}

1 Andrews, N. C. Disorders of iron metabolism. The New England journal of medicine 341, 1986-1995, doi:10.1056/NEJM199912233412607 (1999).

2 Anderson, G. J. \& Vulpe, C. D. Mammalian iron transport. Cell Mol Life Sci 66, 3241-3261, doi:10.1007/s00018-009-0051-1 (2009).

3 Jankowska, E. A., von Haehling, S., Anker, S. D., Macdougall, I. C. \& Ponikowski, P. Iron deficiency and heart failure: diagnostic dilemmas and therapeutic perspectives. European heart journal 34, 816-829, doi:10.1093/eurheartj/ehs224 (2013).

4 Rouault, T. A. \& Tong, W. H. Iron-sulphur cluster biogenesis and mitochondrial iron homeostasis. Nat Rev Mol Cell Biol 6, 345-351, doi:10.1038/nrm1620 (2005).

5 Beard, J. L. Iron biology in immune function, muscle metabolism and neuronal functioning. J Nutr 131, 568S-579S; discussion 580S, doi:10.1093/jn/131.2.568S (2001).

6 Anker, S. D. et al. Ferric carboxymaltose in patients with heart failure and iron deficiency. The New England journal of medicine 361, 2436-2448, doi:10.1056/NEJMoa0908355 (2009).

7 Ponikowski, P. et al. Beneficial effects of long-term intravenous iron therapy with ferric carboxymaltose in patients with symptomatic heart failure and iron deficiencydagger. European heart journal 36, 657-668, doi:10.1093/eurheartj/ehu385 (2015).

8 van Veldhuisen, D. J. et al. Effect of Ferric Carboxymaltose on Exercise Capacity in Patients With Chronic Heart Failure and Iron Deficiency. Circulation 136, 1374-1383, doi:10.1161/CIRCULATIONAHA.117.027497 (2017).

9 Klip, I. T. et al. Iron deficiency in chronic heart failure: an international pooled analysis. American heart journal 165, 575-582 e573, doi:10.1016/j.ahj.2013.01.017 (2013).

10 van Veldhuisen, D. J., Anker, S. D., Ponikowski, P. \& Macdougall, I. C. Anemia and iron deficiency in heart failure: mechanisms and therapeutic 
approaches. Nat Rev Cardiol 8, 485-493, doi:10.1038/nrcardio.2011.77 (2011).

11 Zeller, T. et al. Adverse Outcome Prediction of Iron Deficiency in Patients with Acute Coronary Syndrome. Biomolecules 8: 60, doi:10.3390/biom8030060 (2018).

12 Cosentino, N. et al. Iron deficiency in patients with ST-segment elevation myocardial infarction undergoing primary percutaneous coronary intervention. International journal of cardiology 300, 14-19, doi:10.1016/j.ijcard.2019.07.083 (2020).

13 Moher, D., Liberati, A., Tetzlaff, J., Altman, D. G. \& Group, P. Preferred reporting items for systematic reviews and meta-analyses: the PRISMA statement. PLoS Med 6, e1000097, doi:10.1371/journal.pmed.1000097 (2009).

14 Amsterdam, E. A. et al. 2014 AHA/ACC guideline for the management of patients with non-ST-elevation acute coronary syndromes: a report of the American College of Cardiology/American Heart Association Task Force on Practice Guidelines. Circulation 130, e344-426, doi:10.1161/CIR.0000000000000134 (2014).

15 Hayden, J. A., van der Windt, D. A., Cartwright, J. L., Cote, P. \& Bombardier, C. Assessing bias in studies of prognostic factors. Annals of internal medicine 158, 280-286, doi:10.7326/0003-4819-158-4-20130219000009 (2013).

16 Gonzalez-D'Gregorio, J. et al. Iron deficiency and long-term mortality in elderly patients with acute coronary syndrome. Biomarkers in medicine 12, 987-999, doi:10.2217/bmm-2018-0021 (2018).

17 Martins, J. R. P. et al. Does iron deficiency have any prognostic impact in acute coronary syndromes? European heart journal 36, 920-920 (2015).

18 Fujinaga, H., Okumura, T. \& Harada, K. IRON DEFICIENCY PREDICTS POOR OUTCOMES AFTER PRIMARY INTERVENTION IN NONANEMIC PATIENTS WITH STEMI. Journal of the American College of Cardiology 61, E206E206, doi:10.1016/s0735-1097(13)60207-7 (2013).

19 Paeres, A. E. et al. Iron deficency and heart failure go hand in hand, but what about iron deficiency and acute coronary syndrome in an ageing population? The iron paradox. European heart journal 39, 704-704 (2018).

20 Meroño, O. et al. Iron Deficiency Is a Determinant of Functional Capacity and Health-related Quality of Life 30 Days After an Acute Coronary Syndrome. Revista espanola de cardiologia (English ed.) 70, 363-370, doi:10.1016/j.rec.2016.10.004 (2017).

21 Chouchani, E. T. et al. Cardioprotection by S-nitrosation of a cysteine switch on mitochondrial complex I. Nature medicine 19, 753-759, doi:10.1038/nm.3212 (2013).

22 Chouchani, E. T. et al. Ischaemic accumulation of succinate controls reperfusion injury through mitochondrial ROS. Nature 515, 431-435, doi:10.1038/nature13909 (2014).

23 Fuernau, G. et al. Catalytic iron in acute myocardial infarction complicated by cardiogenic shock - A biomarker substudy of the IABP-SHOCK II-trial. International journal of cardiology 227, 83 - 88, doi:10.1016/j.ijcard.2016.11.072 (2017). 
24 Sulieman, M. et al. Serum chelatable redox-active iron is an independent predictor of mortality after myocardial infarction in individuals with diabetes. Diabetes care 27, 2730-2732, doi:10.2337/diacare.27.11.2730 (2004).

25 Ambrosio, G., Zweier, J. L., Jacobus, W. E., Weisfeldt, M. L. \& Flaherty, J. T. Improvement of postischemic myocardial function and metabolism induced by administration of deferoxamine at the time of reflow: the role of iron in the pathogenesis of reperfusion injury. Circulation 76, 906-915, doi:10.1161/01.cir.76.4.906 (1987).

26 van der Kraaij, A. M., Mostert, L. J., van Eijk, H. G. \& Koster, J. F. Iron-load increases the susceptibility of rat hearts to oxygen reperfusion damage. Protection by the antioxidant $(+)$-cyanidanol-3 and deferoxamine. Circulation 78, 442-449, doi:10.1161/01.cir.78.2.442 (1988).

27 Chan, W. et al. Effect of iron chelation on myocardial infarct size and oxidative stress in ST-elevation-myocardial infarction. Circulation. Cardiovascular interventions 5, 270-278, doi:10.1161/CIRCINTERVENTIONS.111.966226 (2012).

28 Schrage, B. et al. Iron deficiency is a common disorder in general population and independently predicts all-cause mortality: results from the Gutenberg Health Study. Clin Res Cardiol, doi:10.1007/s00392-02001631-y (2020).

29 Griffiths, J. D. et al. Acute changes in iron metabolism following myocardial infarction. American journal of clinical pathology 84, 649-654, doi:10.1093/ajcp/84.5.649 (1985).

30 van der Schouw, Y. T. et al. Iron status in the acute phase and six weeks after myocardial infarction. Free radical biology \& medicine 8, 47-53, doi:10.1016/0891-5849(90)90143-7 (1990).

31 Grote Beverborg, N. et al. Definition of Iron Deficiency Based on the Gold Standard of Bone Marrow Iron Staining in Heart Failure Patients. Circ Heart Fail 11, e004519, doi:10.1161/CIRCHEARTFAILURE.117.004519 (2018). 


\section{Figure legends}

\section{Figure 1}

Preferred Reporting Items for Systematic Reviews and Meta-Analyses (PRISMA) flow diagram.

\section{Figure 2}

A) Prevalence of iron deficiency in patients with acute coronary syndromes.

Ev/Trt refers to number of patients with ID/all patients. B) In-hospital pooled cardiovascular and overall mortality in patients with ID and without ID (OR $1.239,95 \% \mathrm{Cl} 0.117$ to $13.134, \mathrm{p}=0.859)$. Ev/Trt: number of deaths in ID group/all patients in ID group. Ev/Ctrl: number of deaths in non-ID group/all patients in non-ID group. C) Mean difference of in-hospital LVEF in patients with ID and without ID $(-1.487,95 \% \mathrm{Cl}-3.309$ to $0.336, \mathrm{p}=0.110)$. D) Lower Killip class (I vs. II-IV) in patients with ID and without ID (OR $0.804,95 \% \mathrm{CI}$ 0.472 to 1.369$], p=0.422)$. Ev/Trt: number of patients with ID in lower Killip class (class I)/ all patients in ID group. Ev/Ctrl: number of patients in non-ID group with Killip class I/ all patients in non-ID group. E) Mean difference of creatinine concentrations $(\mathrm{mg} / \mathrm{dl})$ in patients with ID and without ID $(-0.037$, $95 \% \mathrm{Cl}-0.104$ to $0.030, p=0.277) . I^{\wedge} 2$ refers to $I^{2}$ as a measure of heterogeneity. Continuous random effects model used in all meta-analyses. 
Table 1 Summary of included studies

\begin{tabular}{|c|c|c|c|c|c|c|c|c|c|c|c|}
\hline Study & $\begin{array}{l}\text { Type of } \\
\text { study }\end{array}$ & $\begin{array}{l}\text { Length } \\
\text { of } \\
\text { follow } \\
\text { up }\end{array}$ & $\begin{array}{l}\text { Number } \\
\text { of } \\
\text { centers/ } \\
\text { sites }\end{array}$ & $\begin{array}{l}\text { Dates of } \\
\text { study }\end{array}$ & $\begin{array}{l}\text { Study } \\
\text { populati } \\
\text { on }(\mathrm{N})\end{array}$ & $\begin{array}{l}\text { N with } \\
\text { ID (\%) }\end{array}$ & $\begin{array}{l}\text { Age in } \\
\text { years } \\
\text { (Median } \\
\text { and IQR or } \\
\text { mean } \pm \text { SD) }\end{array}$ & $\begin{array}{l}\text { Gend } \\
\text { er, \% } \\
\text { femal } \\
\text { e }\end{array}$ & $\begin{array}{l}\text { Primary } \\
\text { outcomes } \\
\text { (as per } \\
\text { current } \\
\text { review) }\end{array}$ & $\begin{array}{l}\text { Important secondary outcomes } \\
\text { (as per current review) }\end{array}$ & $\begin{array}{l}\text { Other key } \\
\text { features } \\
\text { (e.g. conflict } \\
\text { of interest) }\end{array}$ \\
\hline $\begin{array}{l}\text { Cosentino } \\
\text {, et al. }{ }^{12}\end{array}$ & $\begin{array}{l}\text { Prospective } \\
\text { observationa } \\
\text { I study }\end{array}$ & 30 days & 1 & $\begin{array}{l}1 / 10 / 2015- \\
30 / 09 / 2018\end{array}$ & 420 & $237(56)$ & $65 \pm 12$ & 22.6 & Not reported & $\begin{array}{l}\text { 30-day mortality, } \mathrm{n}(\%): 7(3 \%) \text { (ID) } \\
\text { vs. } 10(5 \%) \text { (non-ID), } \mathrm{p}=0.19 \\
\text { In-hospital cardiovascular death, } \mathrm{n}(\%): \\
4(2 \%) \text { (ID) vs. } 8(4 \%) \text { (non-ID), } \mathrm{p}=0.14 \\
\text { Composite of in-hospital cardiovascular } \\
\text { mortality and Killip class } \geq 3: \text { OR } \\
\text { (unadjusted) } 0.48(0.28-0.8795 \% \mathrm{Cl}), \\
\mathrm{p}=0.01 \text { for ID vs. non-ID } \\
\text { Admission hsTropl (ng/L): } 231 \pm 66 \text { (ID) vs. } \\
145 \pm 35 \text { (non-ID) } \\
\text { Other outcomes } \\
\text { Killip class } \geq 3 \\
\text { Mechanical ventilation } \\
\text { Atrial fibrillation } \\
\text { VT/VF } \\
\text { Atrio-ventricular block } \\
\text { AKI } \\
\text { AKI requiring RRT } \\
\text { Infarct size (peak troponin concentrations) } \\
\text {-all non-significant }\end{array}$ & $\begin{array}{l}\text { STEMI } \\
\text { patient only }\end{array}$ \\
\hline $\begin{array}{l}\text { Fujinaga, } \\
\text { et al. }{ }^{18} \\
- \\
\text { Conferenc } \\
\text { e abstract } \\
\text { only }\end{array}$ & $\begin{array}{l}\text { Prospective } \\
\text { observationa } \\
\text { I study }\end{array}$ & $\begin{array}{l}\text { In- } \\
\text { hospital } \\
\text { until } \\
\text { discharg } \\
\text { e }\end{array}$ & $1 ?$ & $\begin{array}{l}\text { ? (Abstract } \\
\text { only) }\end{array}$ & 352 & 169 (48) & $\begin{array}{l}68 \pm 12 \text { (ID); } \\
63 \pm 13 y r s \\
\text { (non-ID) }\end{array}$ & $\begin{array}{l}36 \\
\text { (ID); } \\
17 \\
\text { (non- } \\
\text { ID) }\end{array}$ & Not reported & $\begin{array}{l}\text { In-hospital death: } \\
6.5 \% \text { (ID) vs. } 1.6 \% \text { (non-ID), } p=0.03 \\
\text { Killip class (II-IV): } 30 \% \text { vs. } 20 \%, p=0.04 \\
\text { Complete ST segment resolution: } 58 \% \\
\text { (ID) vs. } 72 \% \text { (non-ID), } p=0.005 \\
\text { LVEF: } 54 \pm 13 \% \text { (ID) versus } 57 \pm 12 \% \text { (non- } \\
\text { ID) } \\
\text { Plasma BNP } 286 \pm 315 \mathrm{pg} / \mathrm{ml} \text { (ID) vs. } \\
184 \pm 227 \mathrm{pg} / \mathrm{ml} \text { (non-ID), } \mathrm{p}=0.001\end{array}$ & Abstract only \\
\hline $\begin{array}{l}\text { Gonzalez- } \\
\text { D'Gregori } \\
\text { o, et al. }{ }^{16}\end{array}$ & $\begin{array}{l}\text { Prospective } \\
\text { observationa } \\
\text { I study }\end{array}$ & $\begin{array}{l}4.7 \\
\text { years } \\
\text { (median, } \\
\text { IQR 2- } \\
5.4 \text { ) }\end{array}$ & 1 & $\begin{array}{l}1 / 10 / 2010- \\
1 / 02 / 2012\end{array}$ & 252 & $\begin{array}{l}151 \\
(59.9)\end{array}$ & $78 \pm 7$ & 44.4 & $\begin{array}{l}\text { All cause } \\
\text { mortality - } \\
\text { trend } \\
\text { towards } \\
\text { increased all } \\
\text { cause } \\
\text { mortality } \\
\text { with ID. No } \\
\text { numerical } \\
\text { values }\end{array}$ & None reported for ID & $\begin{array}{l}\text { Q1 (TSAT) } \\
\text { HR 1.54 } \\
\text { [95\% Cl: } \\
1.03-2.30] \\
p=0.035\end{array}$ \\
\hline
\end{tabular}




\begin{tabular}{|c|c|c|c|c|c|c|c|c|c|c|c|}
\hline & & & & & & & & & provided & & \\
\hline $\begin{array}{l}\text { Martins, } \\
\text { et al. }{ }^{17} \\
\text { - } \\
\text { Conferenc } \\
\text { e abstract } \\
\text { only }\end{array}$ & $\begin{array}{l}\text { Prospective } \\
\text { observationa } \\
\text { I study }\end{array}$ & $\begin{array}{l}6 \\
\text { months }\end{array}$ & 1 & “1 year" & 543 & $\begin{array}{l}189 \\
(37.9)\end{array}$ & $?$ & $?$ & $\begin{array}{l}6 \text { months } \\
\text { mortality: } \\
9.5 \% \text { ID vs. } \\
3.1 \% \text { non- } \\
\text { ID, } p=0.004\end{array}$ & $\begin{array}{l}\text { In-hospital MACE (41\% ID vs. } 18 \% \text { non- } \\
\text { ID; } p<0.001\end{array}$ & $\begin{array}{l}\text { Functional ID } \\
(\text { TSAT }<20 \% \text {, } \\
\text { ferritin }>100 \\
\mu \mathrm{g} / \mathrm{L}) 6 \\
\text { months } \\
\text { mortality: } \\
\text { HR } 2.9 \text {, } \\
\mathrm{p}=0.023 \\
\\
\text { Abstract only }\end{array}$ \\
\hline $\begin{array}{l}\text { Meroño, } \\
\text { et al. }{ }^{20}\end{array}$ & $\begin{array}{l}\text { Prospective } \\
\text { observationa } \\
\text { I study }\end{array}$ & 30 days & 1 & $\begin{array}{l}11 / 2012- \\
10 / 2015\end{array}$ & 244 & $\begin{array}{l}139(57) \\
\text { day } 5 \\
102 \\
(46 \%) \text { at } \\
\text { day } 30\end{array}$ & $\begin{array}{l}61 \pm 12 \text { (ID); } \\
67 \pm 15 \\
\text { (non-ID) }\end{array}$ & 26.6 & Not reported & $\begin{array}{l}\text { Exercise (treadmill) capacity at } 30 \text { days: } \\
7.9 \pm 2.9 \text { (ID) vs. } 9.3 \pm 2.6 \text { (non-ID) METS; } P \\
=0.003 \text { and } 366 \pm 162 \text { (ID) vs. } 462 \pm 155 \\
\text { (non-ID) seconds; } P<0.001 . \\
\text { Quality of Life measurements: } \\
\text { Points in VAS, } 72 \pm 17 \text { (non-ID) vs. } 66 \pm 16 \\
\text { (ID), } P=0.008, E Q-5 D, 0.84 \pm 0.16 \text { (non-ID) } \\
\text { vs. } 0.76 \pm 0.25 \text { (ID), } P=0.005\end{array}$ & $\begin{array}{l}\text { Only } 7 \text { major } \\
\text { adverse } \\
\text { events in } \\
\text { study period, } \\
\text { therefore not } \\
\text { formally } \\
\text { evaluated. } \\
\text { Iron status } \\
\text { measured at } \\
\text { day } 5\end{array}$ \\
\hline $\begin{array}{l}\text { Paeres, et } \\
\text { al. }{ }^{19}- \\
\text { Conferenc } \\
\text { e abstract } \\
\text { only }\end{array}$ & $\begin{array}{l}\text { Retrospectiv } \\
\text { e cross- } \\
\text { sectional }\end{array}$ & 30 days & $\begin{array}{l}\text { Not } \\
\text { reported }\end{array}$ & Not reported & 174 & $98(56)$ & $84 \pm 4$ & 45 & Not reported & $\begin{array}{l}\text { LVEF at } 30 \text { days: } 51.6 \% \text { in non-ID vs. } \\
55.5 \% \text { in ID, } p=0.04 \\
\text { Non-ID: higher troponin I peak ( } 30 \mathrm{ng} / \mathrm{ml} \\
\text { vs. } 14 \mathrm{ng} / \mathrm{ml}, p=0.05 \text { ), worse Killip class at } \\
\text { admission (Killip } \geq 2: 26 \% \text { vs. } 20 \% \text {; } p=0.02 \text { ) }\end{array}$ & Abstract only \\
\hline $\begin{array}{l}\text { Zeller, et } \\
\text { al. }{ }^{11}\end{array}$ & $\begin{array}{l}\text { Retrospectiv } \\
\text { e subgroup } \\
\text { analysis } \\
\text { (ACS cases) } \\
\text { of } \\
\text { prospective } \\
\text { cohort study }\end{array}$ & $\begin{array}{l}4 \text { years } \\
\text { (median) }\end{array}$ & 2 & $\begin{array}{l}06 / 1999- \\
03 / 2000\end{array}$ & 836 & $\begin{array}{l}243 \\
(29.1)\end{array}$ & $63(54-70)$ & 24 & $\begin{array}{l}\text { Non-fatal MI } \\
\text { and } \\
\text { cardiovascul } \\
\text { ar mortality: } \\
\text { ID vs. non- } \\
\text { ID, HR } 1.52 \text {, } \\
(95 \% \text { Cl } \\
1.03 \text { to } 2.26 \\
\text { p }=0.037)\end{array}$ & Not reported & \\
\hline
\end{tabular}


Table 2 Risk of Bias assessments of included studies

\begin{tabular}{|c|c|c|c|c|c|c|}
\hline Study & $\begin{array}{l}\text { Study } \\
\text { Participation }\end{array}$ & Study attrition & $\begin{array}{l}\text { Prognostic factor } \\
\text { measurement }\end{array}$ & $\begin{array}{l}\text { Outcome } \\
\text { measurement }\end{array}$ & $\begin{array}{l}\text { Study } \\
\text { confounding }\end{array}$ & $\begin{array}{l}\text { Statistical } \\
\text { analysis and } \\
\text { reporting }\end{array}$ \\
\hline $\begin{array}{l}\text { Cosentino, et al. } \\
12\end{array}$ & $\begin{array}{l}\text { Moderate } \\
\text { STEMI patients only. }\end{array}$ & Low & Low & Low & $\begin{array}{l}\text { Low } \\
\text { Adjustment for major } \\
\text { confounders including } \\
\text { anemia, diabetes, } \\
\text { admission troponin I. }\end{array}$ & Low \\
\hline $\begin{array}{l}\text { Fujinaga, et al. } \\
18 \text { - abstract only }\end{array}$ & $\begin{array}{l}\text { Moderate } \\
\text { STEMl patients only. } \\
\text { Abstract only. }\end{array}$ & $\begin{array}{l}\text { Low } \\
\text { In-hospital outcomes } \\
\text { only. }\end{array}$ & $\begin{array}{l}\text { Low } \\
\text { Abstract only. }\end{array}$ & $\begin{array}{l}\text { Low } \\
\text { Abstract only. }\end{array}$ & $\begin{array}{l}\text { High } \\
\text { Abstract only. } \\
\text { Confounders } \\
\text { considered (e.g. age), } \\
\text { but no mention of } \\
\text { adjustment in analysis } \\
\text { (abstract only). }\end{array}$ & $\begin{array}{l}\text { High } \\
\text { Abstract only. }\end{array}$ \\
\hline $\begin{array}{l}\text { Gonzalez- } \\
\text { D'Gregorio, et al. } \\
16\end{array}$ & $\begin{array}{l}\text { Moderate } \\
\text { Only patients older } \\
\text { than } 65 \text { years included. }\end{array}$ & $\begin{array}{l}\text { Moderate } \\
\text { Attrition rate not } \\
\text { reported. }\end{array}$ & Low & Low & $\begin{array}{l}\text { Medium } \\
\text { Confounders } \\
\text { considered in analysis } \\
\text { of TSAT as predictor } \\
\text { but not in classical ID } \\
\text { vs. Non-ID definition. }\end{array}$ & $\begin{array}{l}\text { Moderate } \\
\text { Data presented for ID } \\
\text { vs. Non-ID in Figure } \\
\text { only. Underlying data } \\
\text { values not provided. } \\
\text { No description of } \\
\text { censoring in survival } \\
\text { analysis. }\end{array}$ \\
\hline $\begin{array}{l}\text { Martins, et al. }{ }^{17} \\
\text { - abstract only }\end{array}$ & $\begin{array}{l}\text { Medium } \\
\text { "ACS" patients, } \\
\text { suggesting wide range } \\
\text { of patients } \\
\text { participating. } \\
\text { Abstract only. }\end{array}$ & $\begin{array}{l}\text { Moderate } \\
\text { Attrition rate not } \\
\text { reported for } 6 \text { months } \\
\text { follow-up. Abstract } \\
\text { only. }\end{array}$ & $\begin{array}{l}\text { Low } \\
\text { Abstract only }\end{array}$ & $\begin{array}{l}\text { Low } \\
\text { Abstract only }\end{array}$ & $\begin{array}{l}\text { Moderate } \\
\text { Adjusted analysis for } \\
\text { anemia. Abstract only. }\end{array}$ & $\begin{array}{l}\text { High } \\
\text { Abstract only. }\end{array}$ \\
\hline Meroño, et al. ${ }^{20}$ & Moderate & $\begin{array}{l}\text { High } \\
\text { High attrition for } \\
\text { measurement of } \\
\text { exercise capacity - this } \\
\text { affected ID group } \\
\text { disproportionally. }\end{array}$ & Low & Low & $\begin{array}{l}\text { High } \\
\text { Only some } \\
\text { confounders } \\
\text { considered and } \\
\text { adjusted for. Treadmill } \\
\text { test not feasible "due }\end{array}$ & Low \\
\hline
\end{tabular}




\begin{tabular}{|c|c|c|c|c|c|c|}
\hline & & & & & $\begin{array}{l}\text { to severe } \\
\text { osteoarthritis, } \\
\text { peripheral artery } \\
\text { disease, loss of } \\
\text { balance, and/or } \\
\text { suboptimal adaptation } \\
\text { to the treadmill". Most } \\
\text { of these co-morbidities } \\
\text { have not been (or } \\
\text { cannot be) adjusted } \\
\text { for. }\end{array}$ & \\
\hline $\begin{array}{l}\text { Paeres, et al. }{ }^{19} \\
\text { - abstract only }\end{array}$ & $\begin{array}{l}\text { High } \\
\text { Patients above } 80 \\
\text { years only. } \\
\text { Abstract only. }\end{array}$ & $\begin{array}{l}\text { Moderate } \\
30 \text { day follow up only, } \\
\text { therefore unlikely, } \\
\text { however, abstract only. }\end{array}$ & $\begin{array}{l}\text { Low } \\
\text { Abstract only. }\end{array}$ & $\begin{array}{l}\text { Low } \\
\text { Abstract only. }\end{array}$ & $\begin{array}{l}\text { High } \\
\text { Abstract only. } \\
\text { Confounders } \\
\text { considered (e.g. age, } \\
\text { hypertension, multi- } \\
\text { vessel disease), but no } \\
\text { mention of adjustment } \\
\text { in analysis (abstract } \\
\text { only). }\end{array}$ & $\begin{array}{l}\text { High } \\
\text { Abstract only. }\end{array}$ \\
\hline Zeller, et al. ${ }^{11}$ & $\begin{array}{l}\text { Low } \\
\text { Retrospective analysis } \\
\text { of patients with } \\
\text { laboratory data } \\
\text { available. }\end{array}$ & $\begin{array}{l}\text { Low } \\
87.2 \% \text { followed up in } \\
\text { clinic, others were } \\
\text { interviewed by } \\
\text { telephone. }\end{array}$ & Low & Low & $\begin{array}{l}\text { Low } \\
\text { Adjustment for major } \\
\text { confounders including } \\
\text { anemia, diabetes, NT- } \\
\text { proBNP, age, sex, } \\
\text { smoking status. }\end{array}$ & $\begin{array}{l}\text { Moderate } \\
\text { Data presented for ID } \\
\text { vs. Non-ID in Figure } \\
\text { only. Underlying data } \\
\text { values not provided. } \\
\text { No description of } \\
\text { censoring in survival } \\
\text { analysis. }\end{array}$ \\
\hline
\end{tabular}




\section{Figures}

\section{Figure 1}

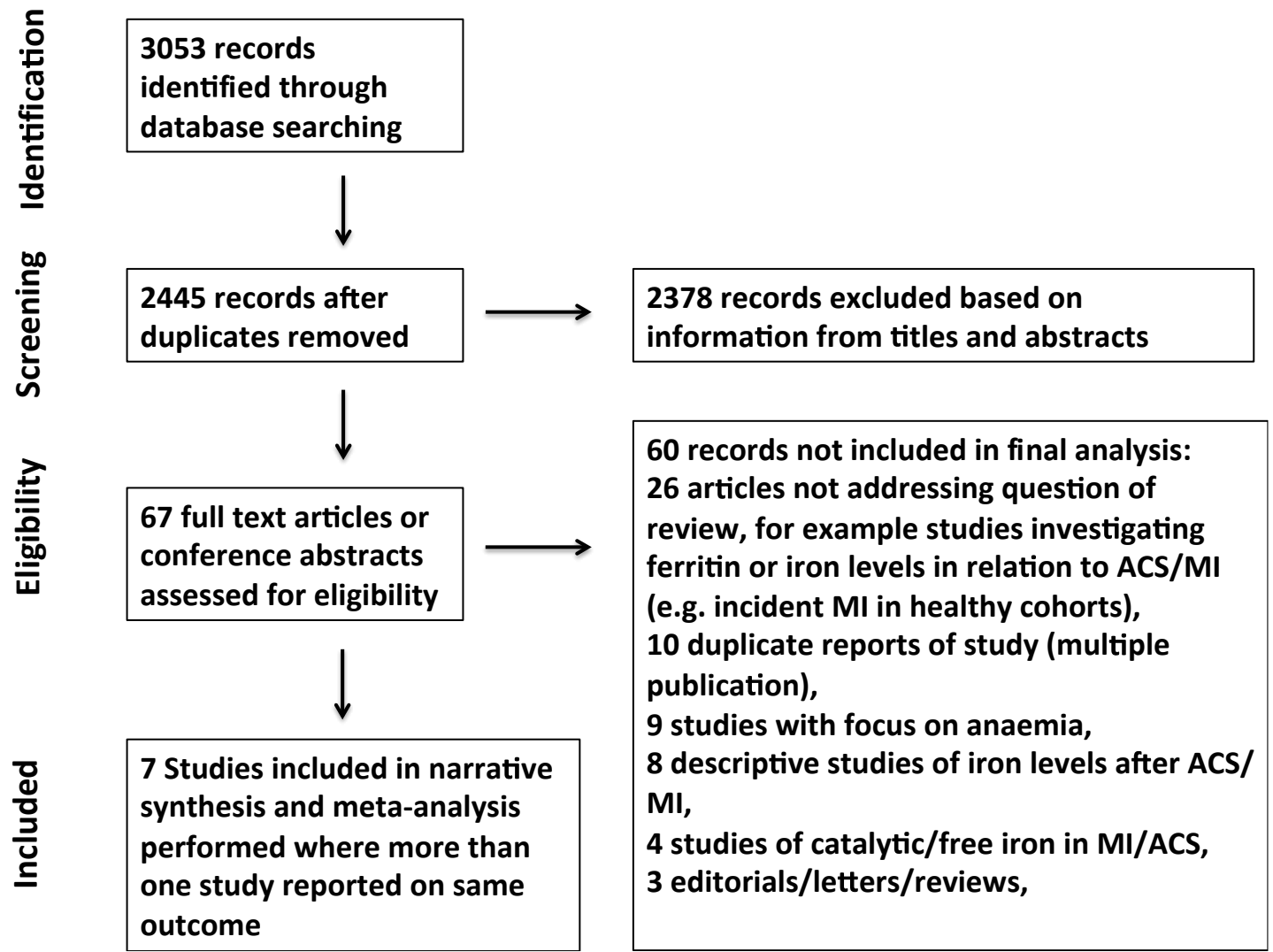




\section{Figure 2}

A) Prevalence of iron deficiency

\section{Studies}

Cosentino 2020

Fujinaga 2013

Gonzales-D'gregorio 2018

Martins 2015

Merono 2017

Paeres 2018

Zeller 2019
Estimate (95\% C.I.) Ev/Trt

$0.564(0.517,0.612) \quad 237 / 420$

$0.480(0.428,0.532) \quad 169 / 352$

$0.599(0.539,0.660) \quad 151 / 252$

$0.348(0.308,0.388) \quad 189 / 543$

$0.570(0.508,0.632) \quad 139 / 244$

$0.563(0.490,0.637) \quad 98 / 174$

$0.291(0.260,0.321) \quad 243 / 836$

Overall $\left(I^{\wedge} 2=9686 \%, P<0.001\right) \quad 0.486(0.383,0.589) \quad 1226 / 2821$

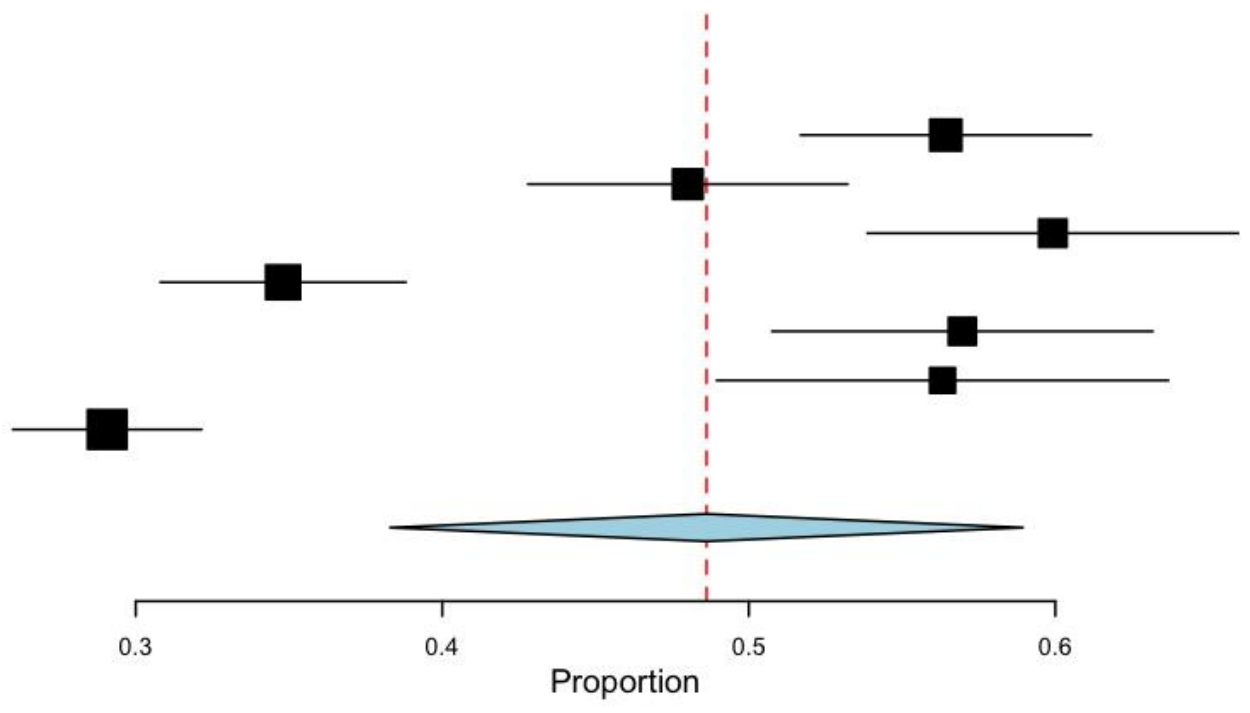


B) In-hospital pooled cardiovascular and overall mortality

Studies

Cosentino 2020

Fujinaga 2013

Overall $\left(I^{\wedge} 2=8585 \%, P=0.008\right) 1.239(0.117,13.134) \quad 15 / 406$

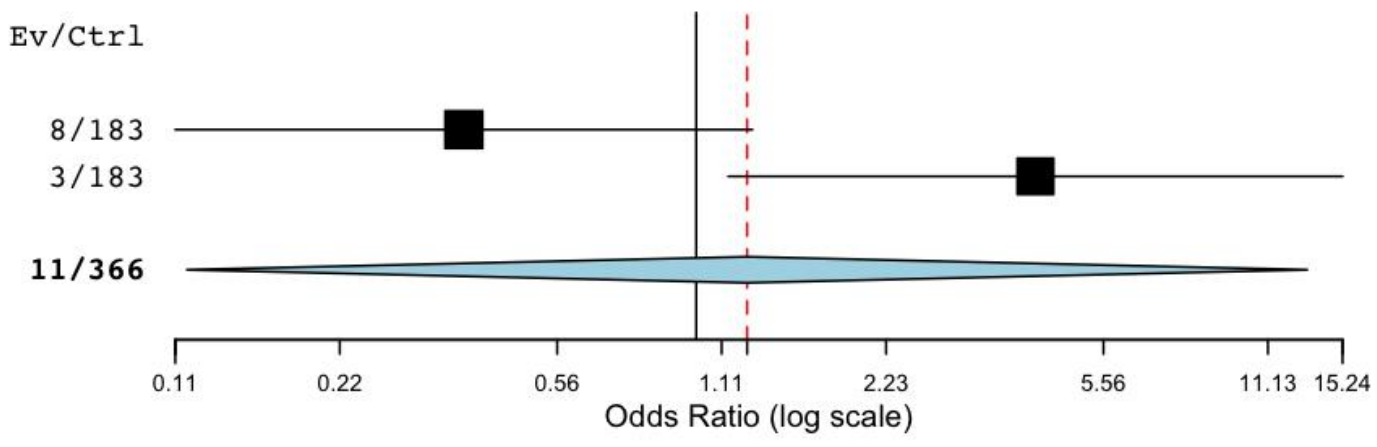


C) In-hospital LVEF

\section{Studies}

Cosentino 2020

Fujinaga 2013

Merono 2017

Overall (I^2=4536 \%, P=0.160)
Estimate ( $95 \%$ C.I.)

$$
\begin{array}{rrr}
0.000 & (-1.929, & 1.929) \\
-3.000 & (-5.620, & -0.380) \\
-2.000 & (-4.511, & 0.511)
\end{array}
$$

$-1.487(-3.309,0.336)$

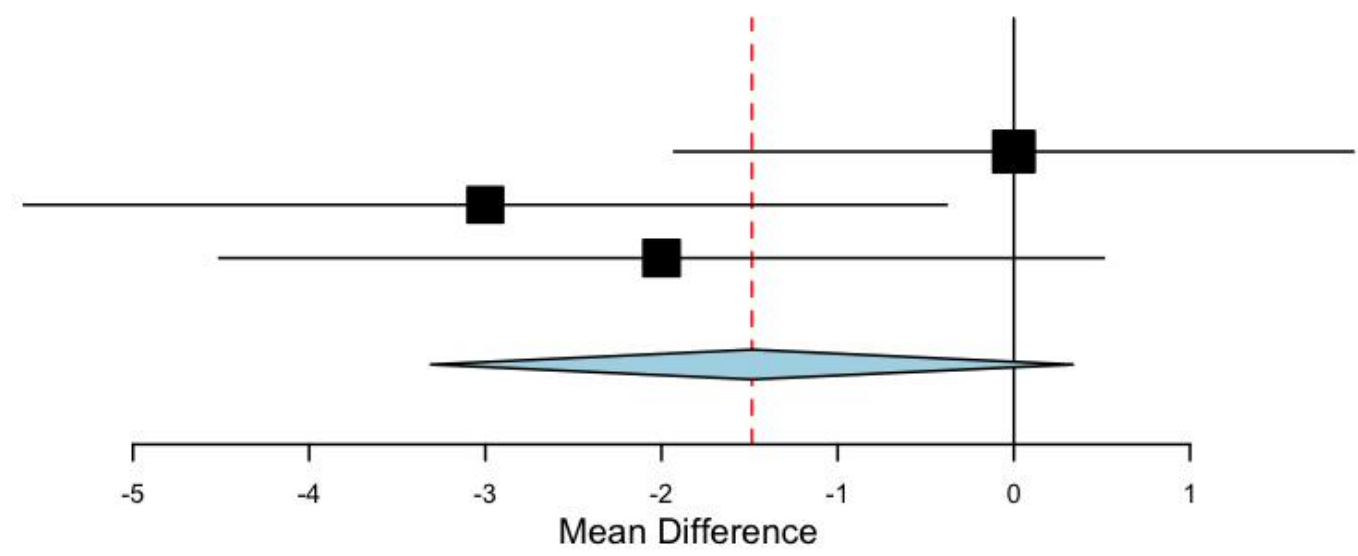


D) Killip class (I vs. II-IV)

Studies

Fujinaga 2013

Merono 2017

Paeres 2018

Overall $\left(I^{\wedge} 2=4903 \%, P=0.141\right) \quad 0.804 \quad(0.472,1.369) \quad 317 / 406 \quad 297 / 364$
Estimate (95\% C.I.) Ev/Trt Ev/Ctrl

$0.586(0.360,0.955) \quad 118 / 169146 / 183$

$0.708(0.312,1.604) 121 / 13995 / 105$

$1.393(0.686,2.829) \quad 78 / 98 \quad 56 / 76$

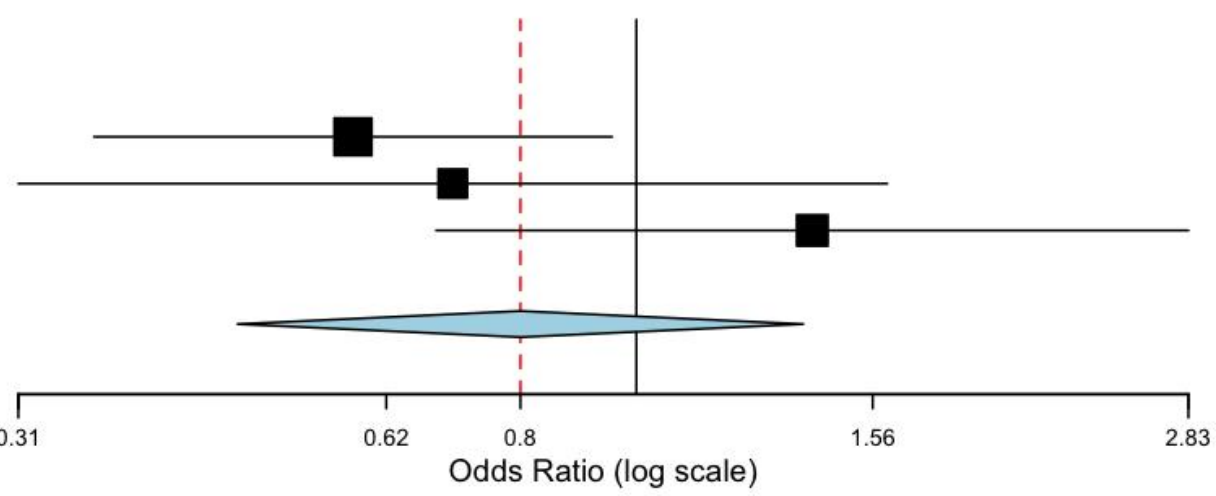


E) Creatinine

Studies

Cosentino 2020

Merono 2017

Overall $\left(\left.\right|^{\wedge} 2=0 \%, P=0.756\right)-0.037 \quad(-0.104,0.030)$

$-0.040(-0.109,0.029)$

$0.000(-0.243,0.243)$
Estimate (95\% C.I.)

$\longleftarrow$

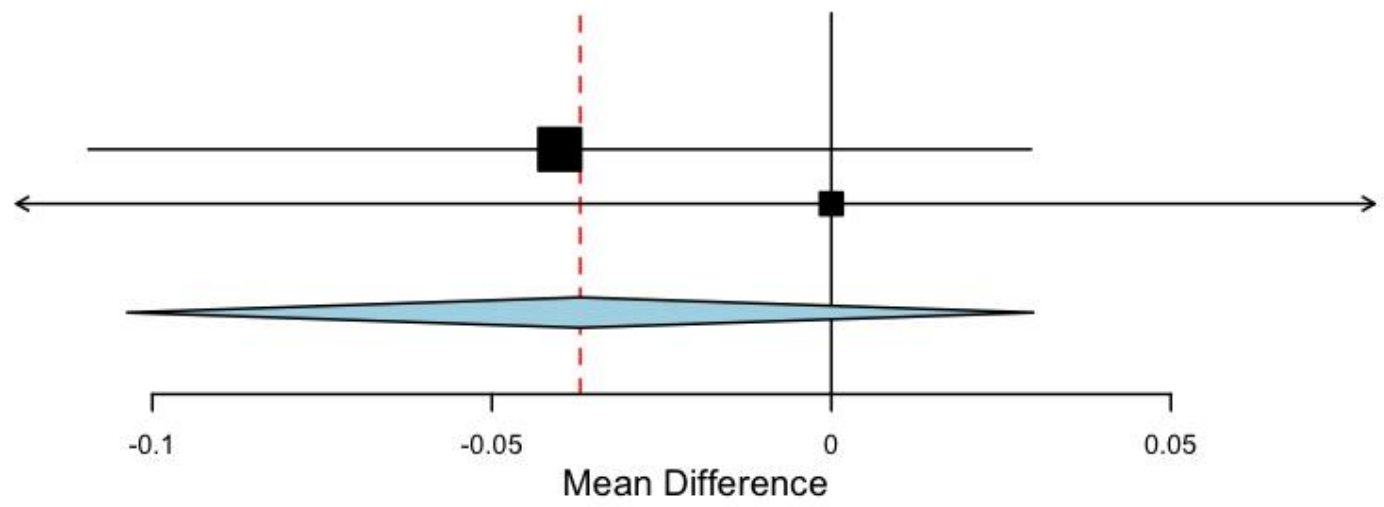

